\title{
Dynamic changes in functional gene copy numbers and microbial communities during degradation of pyrene in soils
}

\author{
Jing-Jing Peng ${ }^{\mathrm{a}, \mathrm{b}}$, Chao Cai ${ }^{\mathrm{a}}$, Min Qiao ${ }^{\mathrm{b}}$, Hong $\mathrm{Li}^{\mathrm{c}}$, Yong-Guan Zhu ${ }^{\mathrm{a}, \mathrm{b}, *}$ \\ ${ }^{a}$ Key Laboratory of Urban Environment and Health, Institute of Urban Environment, Chinese Academy of Sciences, Xiamen 361021, China \\ ${ }^{\mathrm{b}}$ State Key Laboratory of Urban and Regional Ecology, Research Center for Eco-environmental Sciences, Chinese Academy of Sciences, Beijing 100085, China \\ ${ }^{\mathrm{C}}$ Lancaster Environment Centre, Lancaster University, Lancaster LA1 4YQ United Kingdom \\ nidA gene and fast-growing PAH-degrading Mycobacterium can serve as indicators for pyrene contamination.
}

\section{A R T I C L E I N F O}

\section{Article history:}

Received 13 April 2010

Received in revised form

1 June 2010

Accepted 10 June 2010

\section{Keywords:}

Pyrene

nidA

qPCR

Mycobacterium

T-RFLP

Bacterial community

\begin{abstract}
A B S T R A C T
This study investigates the dynamics of pyrene degradation rates, microbial communities, and functional gene copy numbers during the incubation of pyrene-spiked soils. Spiking pyrene to the soil was found to have negligible effects on the bacterial community present. Our results demonstrated that there was a significant difference in nidA gene copy numbers between sampling dates in QZ soil. Mycobacterium 16S rDNA clone libraries showed that more than $90 \%$ mycobacteria detected were closely related to fastgrowing PAH-degrading Mycobacterium in pyrene-spiked soil, while other sequences related to slowgrowing Mycobacterium were only detected in the control soil. It is suggested that nidA gene copy number and fast-growing PAH-degrading Mycobacterium could be used as indicators to predict pyrene contamination and its degradation activity in soils.
\end{abstract}

(c) 2010 Elsevier Ltd. All rights reserved.

\section{Introduction}

The environmental fate of PAH is of concern because of their mutagenicity, ecotoxicity, and carcinogenic potential of high molecular weight PAH. Microbial degradation is the major process involved in the decontamination of surface soil (Sims et al., 1990). Pyrene arising from incomplete combustion of hydrocarbons is a widespread pollutant in the soil environment, and, it is one of the most predominant $\mathrm{PAH}$ in the environment. Thus, a deeper understanding of the microbial degradation pyrene will facilitate better ways to migrate and remediate PAH pollution.

Many bacteria using pyrene as the sole carbon source have been isolated from various environments. The majority of them are Gram-positive. The fast-growing Mycobacterium spp (Miller et al., 2004; Leys et al., 2005), which play a key role in the degradation of high molecular weight $\mathrm{PAH}$, have received particular attention. In addition, some pyrene-degrading $\gamma$-Proteobacteria, such as enteric bacterium Leclercia adecarboxylata, has also been isolated (Eriksson et al., 2002; Sarma et al., 2004). Uncultivated bacteria including $\beta$ - and $\gamma$-Proteobacteria, identified by DNA-based stable isotopic

\footnotetext{
* Corresponding author.

E-mail address: ygzhu@rcees.ac.cn (Y.-G. Zhu).
}

probing, are also primary pyrene degraders (Singleton et al., 2006) However, knowledge of pyrene-degrading bacterial populations is still limited, and mainly originates from studies of cultured bacteria. The characterization of indigenous pyrene-degrading microbial populations is therefore necessary for a better understanding of natural biodegradation processes in and for the successful application of bioremediation technologies.

The initial step of PAH metabolism commonly occurs via the incorporation of molecular oxygen into the aromatic nucleus by a multi-component aromatic ring-hydroxylating-dioxygenase (RHD) enzyme system forming cis-dihydrodiol. RHD is composed of a large $\alpha$ subunit and small $\beta$ subunits (Mason and Cammack, 1992). Functional markers encoding key enzymes of characteristic metabolic pathways can be used to specifically target functional guilds of microorganisms (Lueders and Friedrich, 2003). The most extensively characterized group of pyrene dioxygenase genes, a highly conserved group called nidAB genes, has been identified in certain Mycobacterium species which have been characterized for their ability to degrade high molecular weight PAH (Heitkamp et al., 1988; Khan et al., 2001; Kim et al., 2006). The biochemical pathways of pyrene degradation by Mycobacterium have also been identified (Liang et al., 2006; Kim et al., 2007). The genes encoding the $\alpha$ and $\beta$ subunits of dioxygenases have been sequenced in many strains (Brezna et al., 2003; Sho et al., 2004; Kim et al., 2007). Lake 
sediment studies showed that copy numbers of nidA gene were positively related to pyrene mineralization and nidA gene can serve as a biomarker for pyrene degradation (DeBruyn et al., 2007). However, little is known about the relationship between nidA gene and pyrene degradation in background soils that were not already contaminated by PAHs.

Numerous studies have focused on microbial dynamics in contaminated water, soil and sediments (Cheung and Kinkle, 2005; Debruyn et al., 2009; Debruyn and Sayler, 2009), but few have evaluated the impact of introducing pyrene to microbial communities in background soil. This study aimed to investigate the dynamics of the bacterial community in soils freshly-spiked with pyrene by T-RFLP analysis. This would expand the knowledge of functional marker genes for pyrene degradation from the soil environment. In order to test the hypothesis that nidA gene are enriched in pyrene-spiked soil and functionally related to the degradation of pyrene, quantitative real-time PCR (qPCR) was used to monitor the change of nidA gene copy numbers. To our knowledge, this study is the first to evaluate the relationship between pyrene-biodegradation potential and nidA gene copy numbers in pyrene-spiked to background soil.

\section{Materials and methods}

\subsection{Soils selection and characterization}

Surface soils were collected to a depth of $20 \mathrm{~cm}$ from a site in Quanzhou (QZ) $\left(25^{\circ} 08.414 \mathrm{~N} ; 118^{\circ} 48.384 \mathrm{E}\right)$ and a site in Sanming (SM) $\left(26^{\circ} 18.236 \mathrm{~N} ; 117^{\circ} 30.817 \mathrm{E}\right)$ which were background soils. Soil samples were air-dried and passed $<0.45 \mathrm{~mm}$ sieve-mesh and stored in the dark at $4{ }^{\circ} \mathrm{C}$. Soil class and texture were determined by Malvern Mastersizer 2000 (Malvern Instruments, England). Soil pH was determined in a 1:1 soil: water mixture. Total organic $C$ content was determined by Shimadzu Toc-Vcph analyzer (USA). PAHs were analyzed in triplicate by GC-MS (Agilent $7890 \mathrm{~A} / 5975$, USA) according to EPA method 8270 . The soil characteristics are given in Table 1.

\subsection{Pyrene incubation experiment}

In order to re-activate the soil microorganisms, dry soil samples (500 g) in duplicates were placed in separate glass beakers, moistened with sterile distilled water to the level of $40 \%$ of water holding capacity and incubated at room temperature $\left(25{ }^{\circ} \mathrm{C}\right.$ ) for a period of two weeks (Klimkowicz-Pawlas and Maliszewska-Kordybach, 2003). The soils were then spiked with $1000 \mathrm{mg} \mathrm{L}^{-1}$ solution of pyrene in acetone to a final concentration at $50 \mathrm{mg} \mathrm{kg}^{-1}$, following the recommendations of Brinch et al. (2002) with some adaptations. Briefly, a subsample of $10 \%$ was spiked with the pyrene solution and was mixed by hand shaking in a $1000 \mathrm{ml}$ glass beaker. After evaporation of the acetone (overnight at $25^{\circ} \mathrm{C}$ ), the spiked sub-sample (10\%) was mixed with the rest $(90 \%)$ of the soil, and shaken thoroughly. The moisture content of the samples was adjusted again to $40 \%$ of water holding capacity. $10 \mathrm{~g}$ spiked soil was placed into $50 \mathrm{ml}$ glass bottles which were sealed with sterile parafilm. Un-spiked soils were amended with acetone at the amount corresponding to those used in PAH-spiked soils. All the samples were incubated in the dark at $25^{\circ} \mathrm{C}$. Soil moisture content was kept at the constant level by periodically weighing the samples and adding water as necessary. Triplicate samples were collected on day $0,7,14,21,28,60$, were frozen immediately, and stored at $-20{ }^{\circ} \mathrm{C}$ until analyses. The same procedures were used for the abiotic controls except the soils were autoclaved for three consecutive days before spiking with pyrene solution (Park and Crowley, 2006).

Table 1

Properties of soils from Sanming (SM) and Quanzhou (QZ) in China.

\begin{tabular}{lll}
\hline Properties & SM & QZ \\
\hline Soil texture & Sand & Sand \\
Sand (\%) & 69 & 82 \\
Silt (\%) & 30 & 18 \\
Clay (\%) & 1 & 0 \\
TOC (\%) & 1.17 & 0.88 \\
pH & 4.99 & 5.84 \\
Total PAH $\left(\mathrm{ng} \mathrm{g}^{-1}\right)$ & 69 & 94 \\
Pyrene $\left(\mathrm{ng} \mathrm{g}^{-1}\right)$ & 16 & 13 \\
\hline
\end{tabular}

\subsection{Pyrene quantification}

Analysis of pyrene followed the procedure described earlier (MaliszewskaKordybach et al., 2007). At the time of extraction, $100 \mathrm{mg} \mathrm{kg}^{-1}$ of fluoranthened10 was used as substitute. Soil samples $(1 \mathrm{~g})$ were Soxhlet-extracted with acetone and dichloromethane (1:1) for $48 \mathrm{~h}$ followed by cleaning up on $\mathrm{SiO}_{2}, \mathrm{Na}_{2} \mathrm{SO}_{4}$ and $\mathrm{Al}_{2} \mathrm{O}_{3}$ micro-columns. And $100 \mathrm{mg} \mathrm{kg}^{-1}$ of phenantherene-d10 was used as internal standard to the extractant. Concentrated $(1 \mathrm{ml})$ soil extracts were analyzed using an Agilent gas chromatograph (7890A) equipped with a mass-selective detector (model 5975) and 7683B series autosampler (Agilent Technologies) with the following conditions: Helium was used as a carrier gas (constant velocity of $30 \mathrm{~cm} \mathrm{~s}^{-1}$ ) with a split-less injection system at $250{ }^{\circ} \mathrm{C}$. The GC oven was programmed as follows: $50{ }^{\circ} \mathrm{C}$ for $1 \mathrm{~min}$, followed by a $10^{\circ} \mathrm{C} \mathrm{min}^{-1} \mathrm{ramp}$ to $200{ }^{\circ} \mathrm{C}$ and then with a ramp of $8{ }^{\circ} \mathrm{C} \mathrm{min}-1$ to final temperature of $280^{\circ} \mathrm{C}$ and hold for $10 \mathrm{~min}$. Mass spectrometer detection was using the selected ion monitoring system. The data were the average of three replicates.

\subsection{DNA extraction and $q P C R$ analysis}

Triplicate bottles from each treatment were destructively sampled at various time points. The soil samples were stored frozen at $-20^{\circ} \mathrm{C}$ until DNA extraction. DNA was extracted from $0.5 \mathrm{~g}$ of soil (dry weight) with a FastDNA Spin kit for soil (BIO101) as described by the manufacturer with minor modifications (Dionisi et al., 2004).

Target groups and primer sequences for all qPCR analyses are summarized in Table 2. Total Bacteria were quantified using primers (BACT1369F and PROK1492R) and methods as described by Suzuki et al. (2000). Amplification conditions were $30 \mathrm{~s}$ $94^{\circ} \mathrm{C}, 15 \mathrm{~s} 95{ }^{\circ} \mathrm{C}, 1 \mathrm{~min} 56^{\circ} \mathrm{C}$, in a reaction volume of $25 \mu \mathrm{l}$, containing $12.5 \mu \mathrm{l}$ Premix Ex taq ${ }^{\mathrm{TM}}$ (Takara), $1 \mu \mathrm{l}$ of each $10 \mu \mathrm{M}$ primer (Takara), $0.2 \mu \mathrm{l} 25 \mathrm{mM}$ BSA and $2 \mu \mathrm{l}$ DNA (in 1:10 dilution of original extracts) as templates. A qPCR assay targeting fastgrowing Mycobacterium 16S rDNA genes and pyrene dioxygenase gene nidA (Mycobacterium) were also quantified as described previously (Debruyn and Sayler, 2009). The annealing temperature was $57{ }^{\circ} \mathrm{C}$ and $59{ }^{\circ} \mathrm{C}$, respectively. Amplification reactions were described as above. All the real-time PCR reactions were performed on an $\mathrm{iQ}^{\mathrm{TM}} 5$ thermocycler (BioRad, USA).

The bacterial standard template DNA was generated by PCR with Bacteria- (27f/ 1492r) specific primers. The PCR products were cloned into pGEM-T Easy vector (Promega, USA). Plasmids were transformed into Escherichia coli JM109 cells (Takara). These clones were sequenced and used as an internal standard. For generation of the Mycobacterium and nidA gene standard, Mycobacterium sp. 6PY1 (supported by John C. Willison) used as the template was amplified with Mycobacterium (MycoF/MycoR) and nidA (nidA-F/nidA-R) specific primers and cloned as above. All quantitative PCR reactions were performed in triplicate. Ten-fold serial dilutions of a known copy number of the plasmid DNA were used to perform qPCR assays in triplicate to generate standard curves.

Table 2

Quantitative Real-time PCR primers, PCR primers in this study.

\begin{tabular}{|c|c|c|}
\hline Target group & $\begin{array}{l}\text { Probes and } \\
\text { Primers }\end{array}$ & Sequences \\
\hline \multirow[t]{3}{*}{$\begin{array}{l}\text { Bacteria } \\
\quad(16 S \text { rDNA })\end{array}$} & BACT1369F & $\begin{array}{l}\text { 5'-CGGTGAATACGTTCYCGG } \\
\text { (Suzuki et al., 2000) }\end{array}$ \\
\hline & PROK1492R & $\begin{array}{l}\text { 5'-GGWTACCTTGTTACGACTT } \\
\text { (Suzuki et al., 2000) }\end{array}$ \\
\hline & $\begin{array}{l}\text { Probe } \\
\text { (TM1389F) }\end{array}$ & $\begin{array}{l}\text { 5'-FAM-CTTGTACACACCGCCCGTC-TAMRA } \\
\text { (Suzuki et al., 2000) }\end{array}$ \\
\hline \multirow[t]{3}{*}{ nidA } & NidA-F & $\begin{array}{l}\text { 5'-TTCCCGAGTACGAGGGATAC } \\
\text { (DeBruyn et al., 2007) }\end{array}$ \\
\hline & NidA-R & $\begin{array}{l}\text { 5'-TCACGTTGATGAACGACAAA } \\
\text { (DeBruyn et al., 2007) }\end{array}$ \\
\hline & Probe & $\begin{array}{l}\text { 5'-FAM-TCCTACCCGTCGCCGGTACA-BHQ1 } \\
\text { (DeBruyn et al., 2007) }\end{array}$ \\
\hline \multirow[t]{3}{*}{$\begin{array}{l}\text { Mycobacterium } \\
\text { (16S rDNA) }\end{array}$} & MycoF & $\begin{array}{l}5^{\prime} \text {-CCTTATGTCCAGGGCTTCA } \\
\text { (Debruyn and Sayler, 2009) }\end{array}$ \\
\hline & MycoR & $\begin{array}{l}5^{\prime} \text {-TAGCGACTCCGACTTCACG } \\
\text { (Debruyn and Sayler, 2009) }\end{array}$ \\
\hline & Probe & $\begin{array}{l}\text { 5'-FAM-TTGAAAGGATTCGCTCCACCTCA-BHQ1 } \\
\text { (Debruyn and Sayler, 2009) }\end{array}$ \\
\hline \multirow[t]{2}{*}{$\begin{array}{r}\text { Mycobacterium } \\
\text { (16S rDNA) }\end{array}$} & Myco66f & $\begin{array}{l}\text { 5'-CATGCAAGTCGAACGGAAA } \\
\text { (Leys et al., 2005) }\end{array}$ \\
\hline & Myco600r & $\begin{array}{l}\text { 5'-TGTGAGTTTTCACGAACA } \\
\text { (Leys et al., 2005) }\end{array}$ \\
\hline \multirow[t]{2}{*}{$\begin{array}{l}\text { Bacteria } \\
\quad(16 \mathrm{~S} \text { rDNA) }\end{array}$} & $27 f$ & $\begin{array}{l}\text { 5'-AGAGTTTGATCMTGGCTCAG } \\
\text { (Weisburg et al., 1991) }\end{array}$ \\
\hline & $1492 \mathrm{r}$ & $\begin{array}{l}\text { 5'-TACGGYTACCTTGTTACGACT } \\
\text { (Weisburg et al., 1991) }\end{array}$ \\
\hline
\end{tabular}




\subsection{Bacterial community analysis by T-RFLP analysis}

PCR amplification and T-RFLP analysis of bacterial 16S rDNA fragments followed the protocols described previously (Lueders and Friedrich, 2000; Lu et al., 2006). Briefly, the amplification used 27f and 1492r (Weisburg et al., 1991) and $5^{\prime}$ end of the $27 \mathrm{f}$ primer was labeled with 6 -carboxyfluorescein. The $50 \mu$ reaction mixture contained $1 \mu \mathrm{l}$ of DNA template (in 1:10 dilution of original extracts), $5 \mu \mathrm{l}$ of $10 \times$ buffer, $3.6 \mu \mathrm{l}$ of $25 \mathrm{mM} \mathrm{MgCl}_{2}, 1 \mu \mathrm{l}$ of a $10 \mathrm{mM}$ concentration of the dNTP, $2 \mu \mathrm{l}$ of $10 \mathrm{mg} \mathrm{L}^{-1}$ bovine serum albumin, $1.6 \mu \mathrm{l}$ of each primer $(10 \mu \mathrm{M})$ and $2.5 \mathrm{U}$ of Taq DNA polymerase (Takara). The thermal profile for amplification was as described previously (Rui et al., 2009). The 6-carboxyfluorescein-labeled PCR products were purified using an agarose gel DNA extraction kit (Takara) and digested at $37{ }^{\circ} \mathrm{C}$ overnight by HaeIII (Fermentas, Canada), and the DNA fragments were size separated using a 3130xl Genetic Analyzer (Applied Biosystems) (Peng et al., 2008).

\subsection{Mycobacterium 165 clone library construction and sequencing}

Two clone libraries were constructed. One was for QZ $50 \mathrm{mg} \mathrm{kg}^{-1}$ pyrenetreated soil (QT) on day 60, the other was for QZ control soil (QC) on day 60. The PCR amplification used the primers Myco66F/Myco600R (Leys et al., 2005) as described in Table 2. A touchdown PCR protocol was used as previously. The amplification conditions were $95{ }^{\circ} \mathrm{C} 6 \mathrm{~min}$, then 20 cycles of denaturing at $95{ }^{\circ} \mathrm{C} 30 \mathrm{~s}$, annealing at $55^{\circ} \mathrm{C}-0.5 /$ cycle for $45 \mathrm{~s}$ and extension at $72{ }^{\circ} \mathrm{C} 45 \mathrm{~s}$, followed by 15 cycles with an annealing temperature at $45^{\circ} \mathrm{C}$, finally extension at $72{ }^{\circ} \mathrm{C}$ for $6 \mathrm{~min}$. PCR products were purified and ligated into the pMD19-T easy vector (Promega, USA) according to the manufacturer's instructions. Plasmids were transformed as described above, and more than eighty five clones were randomly selected and sequenced for each clone library. The sequences were submitted to the Genbank database to search for similarity with other Mycobacterium sequences using the Blast alignment tool (NCBI homepage, http://www.ncbi.nlm.nih.gov/BLAST/). Sequences were assembled, aligned, and analyzed with MEGA4 software (Tamura et al., 2007). The phylogenetic tree was constructed using the neighbor-joining method. The sequences obtained in this study have been deposited in the EMBL nucleotide sequence database, accession numbers FN690762-FN690936.

\section{Results}

\subsection{Pyrene degradation}

Pyrene degradation rates in the two soils were monitored separately following the addition of $50 \mathrm{mg} \mathrm{kg}{ }^{-1}$ pyrene. The concentration of pyrene was measured at different incubation times. In QZ soil spiked with pyrene, degradation was noticeable after 7 days, but not statistically significant, and the dissipation of pyrene was significant at the end of the experiment (day 60) and decreased to $9.76 \mathrm{mg} \mathrm{kg}^{-1}$ (Fig. 1). In contrast to the pyrene treatment soil, there was little pyrene disappearance observed in the QZ sterilized soil. For SM soil, no significant pyrene

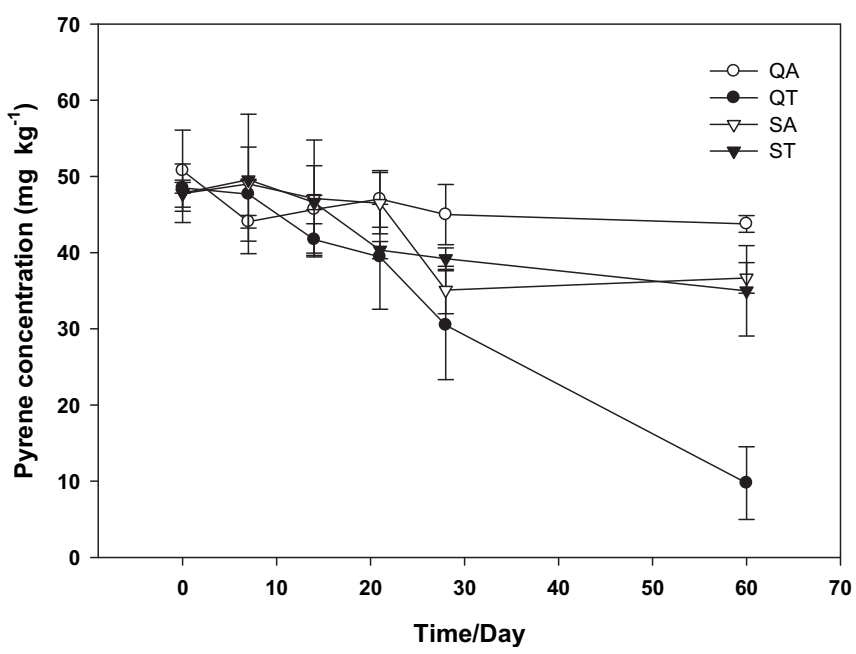

Fig. 1. Dynamics of pyrene concentration in pyrene-spiked soils. QT, soil QZ being spiked with pyrene; QA, soil QZ being sterilized and spiked with pyrene; ST, soil SM being spiked with pyrene; SA, soil SM being sterilized and spiked with pyrene; data are means $\pm \mathrm{SE} ; n=3$. disappearance was observed in both treatments (Fig. 1). The average extraction efficiency was approximately $60 \%$ based on the recovery of a pyrene spike.

\subsection{Analysis of pyrene catabolic genes}

For both soils, the gene copy number of total bacteria ranged from $6 \times 10^{9}$ to $4 \times 10^{10}$ copies $g^{-1}$ dry weight soil in pyrene added soil. There was no significant difference between pyrene treatment and the two control soils (Fig. 2A and B) with the exception of the QZ soil, the bacterial 16S rDNA copy numbers in pyrene treatment were lower than the control (Fig. 2A). The gene copy number of total Mycobacterium 16S rDNA ranged from $1.04 \times 10^{9}$ to $8.63 \times 10^{9}$ copies $\mathrm{g}^{-1}$ of dry weight soil. Statistical analysis showed the data from the quantification of bacterial and Mycobacterium 16S rDNA were not significantly different between sampling dates $(p>0.05)$. For QZ soil, Mycobacterium 16S rDNA copies were higher in pyrene added soil than in the control soil (Fig. 2C). However, for SM soil, the gene copy number of Mycobacterium 16S rDNA was detected at levels just above quantification in the control soil, unlike the pyrene added soil (Fig. 2C and D). For QZ soil, between sampling dates of pyrene added soil, there was a significant difference in the abundance of nidA gene. The nidA gene copy numbers which increased with incubation time ranged from $7.88 \times 10^{3}$ to $3.05 \times 10^{6}$ copies $\mathrm{g}^{-1}$ of dry weight soil (Fig. 2E). But for SM soil, no significant differences were observed for nidA gene copy numbers in the pyrene added soil (Fig. 2F). In addition, the nidA gene copy numbers were not detected (data not shown) in the two control soils, which might be due the fact that the control soils had little pyrene contamination.

\subsection{Structure of microbial community}

The T-RFLP fingerprints of bacterial communities in soils incubated for different periods after the addition of pyrene were compared with those of the control microcosms. Six fragments (191 bp, 194 bp, 214 bp, 222 bp, 228 bp and 231 bp) were detected as major peaks in the T-RFLP profiles (Fig. 3). T-RFLP patterns showed that there were no substantial changes in bacterial community during the 60-day incubation period, neither in pyrene-spiked nor in the control soil. Only some of the major peaks such as T-RFs $191 \mathrm{bp}, 194 \mathrm{bp}$ showed small variations (Fig. 3C and D). In addition, there were no significant changes in bacterial community after the addition of pyrene. However, T-RFLP patterns showed more significant changes in terms of community structure between different soils (Fig. 3).

Detection of nidA gene in QZ soil indicated the existence of fastgrowing, potentially the PAH-degrading Mycobacterium (DeBruyn et al., 2007). To investigate the diversity of Mycobacterium, two clone libraries were constructed. One hundred and seventy six clones were successfully sequenced. A neighbor-joining tree generated using Kimura's two-parameter distance method (Kimura, 1980), is shown in Fig. 4. For the clone library of the pyrene treatment, maximum-likelihood analysis indicated that most sequences fell into the PAH-degrading, fast-growing Mycobacterium clusters, such as $M$. flavescens, $M$. austroafricanum. For the clone library of the control soil, several sequences fell into $M$. gordonae (Rogall et al., 1990) which is the slower-growing Mycobacterium cluster.

\section{Discussion}

In the present study, background soils were used to examine the diversity of bacterial community structure after the addition of pyrene. We firstly evaluated the influence of pyrene addition on 


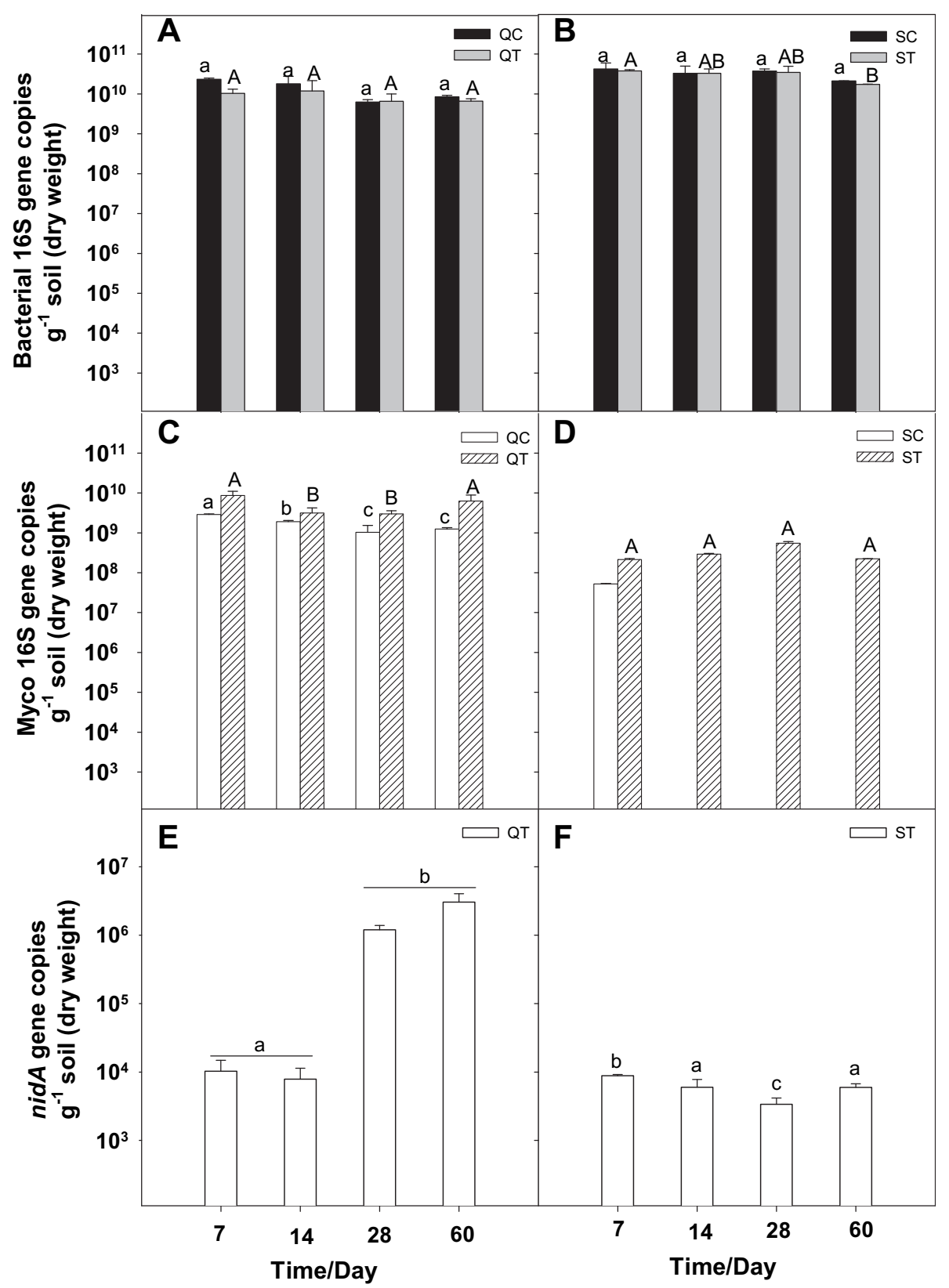

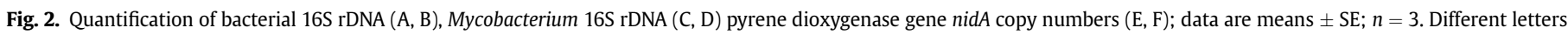
within rows are significantly different $(p<0.05)$ according to one way-ANOVA analysis. QC, QZ control; SC, SM control.

bacterial community using T-RFLP analysis. There was no significant difference in the bacterial community between the pyrenespiked and the control soil. Our data implicated the inherent resistance of the bacterial community to pyrene concentration of $50 \mathrm{mg} \mathrm{kg}{ }^{-1}$. This was similar to the observations that microbial communities could withstand the $\mathrm{Cu}$ or water stress with physiological tolerance (Griffiths et al., 2003; Deng et al., 2009).

Quantification through Real-Time PCR is considered to be an accurate method for estimating the biodegradation potential of a PAH-degrading bacterial consortium in contaminated environments (Cebron et al., 2008). In our experiment, we quantified the bacterial 16S rDNA, Mycobacterium 16S rDNA, nidA gene abundances in two pyrene-spiked soils. 16S rDNA gene was a proxy for bacterial biomass (Kim et al., 2005a). There was little difference in the 16S rDNA gene copy numbers between different treatments, while there was also a decreasing trend observed for 16S rDNA gene copy numbers with the incubation time in both soils. This indicated that there was no significant population change or bacterial biomass change during the incubation period with pyrene. This is similar to previous study showing that 16S rDNA gene copy numbers were not affected by the addition of naphthalene (Park and Crowley, 2006).

In our study, there was a significant difference in pyrene degradation between the two soils. No significant decrease in SM soil was observed over two months incubation with initial pyrene concentrations of $50 \mathrm{mg} \mathrm{kg}^{-1}$. However, for QZ pyrene-spiked soil, pyrene concentrations began to decrease after 7 days (Fig. 1). This might be related to different soil characteristics. The organic content of SM soil was higher than QZ soils (Table 1). Organic matter is related to bioavailability in terms of a) sorbing PAHs so that they are unavailable to microorganisms through uptake through the cell membranes, and b) also influence the desorption 
A

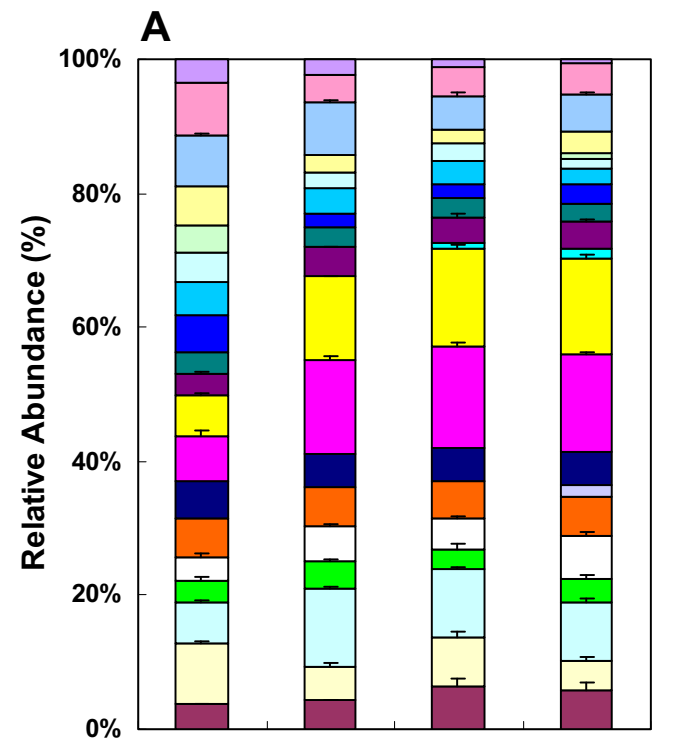

C

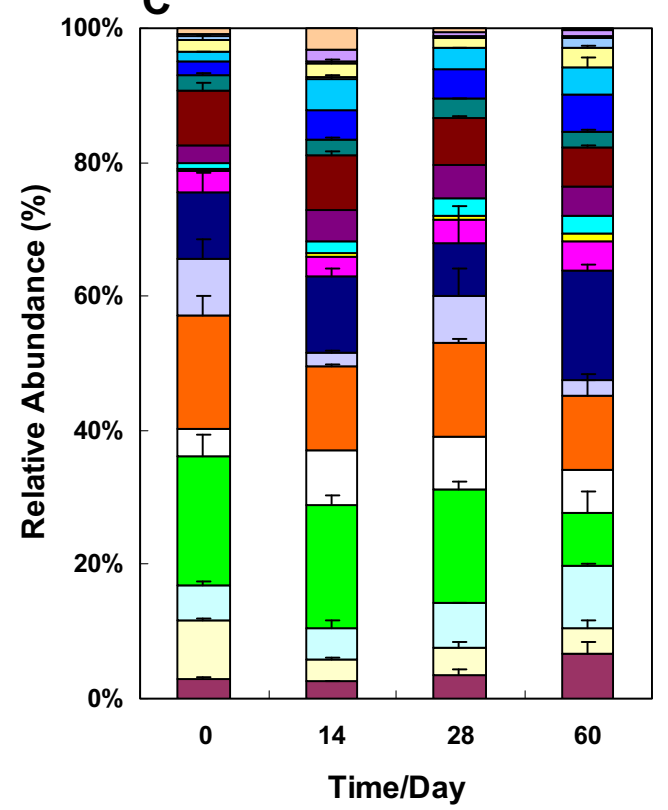

B

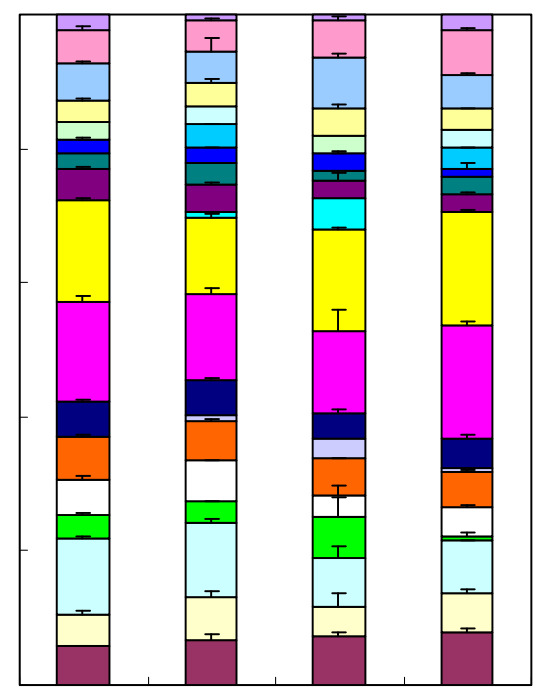

D

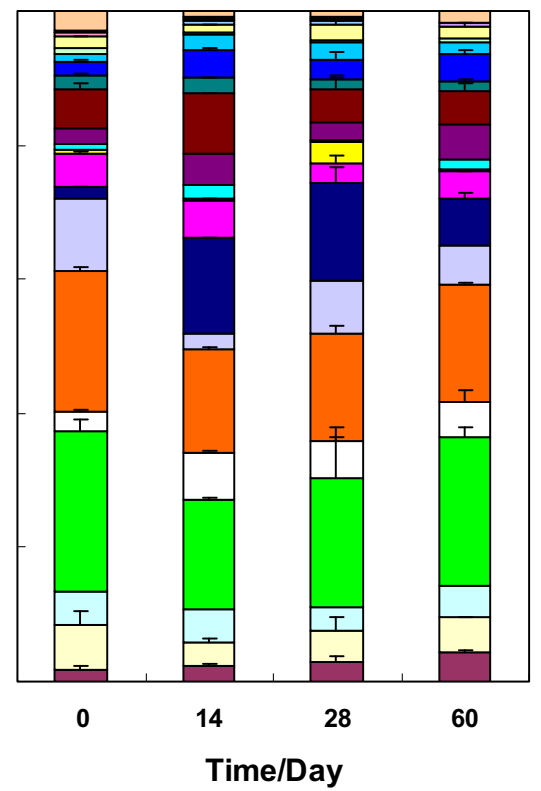

$\square 62 \mathrm{bp} \square 72 \mathrm{bp} \quad \square 191 \mathrm{bp} \square 194 \mathrm{bp} \square 211 \mathrm{bp} \square 214 \mathrm{bp} \square 219 \mathrm{bp} \square 222 \mathrm{bp}$
$\square 228 \mathrm{bp} \square 231 \mathrm{bp} \square 236 \mathrm{bp} \square 238 \mathrm{bp} \square 244 \mathrm{bp} \square 253 \mathrm{bp} \square 266 \mathrm{bp} \square 282 \mathrm{bp}$
$\square 289 \mathrm{bp} \square 291 \mathrm{bp} \square 293 \mathrm{bp} \square 298 \mathrm{bp} \square 309 \mathrm{bp} \square 330 \mathrm{bp} \square 402 \mathrm{bp}$

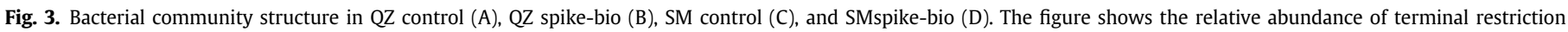
fragments (TRF) used as a measure of the composition of the bacterial community; data are means \pm SE; $n=3$.

kinetics in that there is more organic matter for PAHs to diffuse out of. Organic matter content determined the rate of pyrene transfer from soil to microorganisms (Macleod and Semple, 2002). Hence the pyrene degradation rate of SM soil could be slower than $\mathrm{QZ}$ soil.

In the samples that were used for DNA analysis, the nidA gene copy numbers increased significantly to approximate 500 -fold in QZ soil. The dissipation of pyrene was up to $80 \%$ after 60 -day incubation in $\mathrm{QZ}$ soil. nidA gene responded to pyrene dissipation significantly and suggested that there might be a direct relationship between gene copy numbers and degradation rates for pyrene. This observation was similar to previous studies that there was a positive relationship between nidA gene copy numbers and pyrene mineralization (Wang et al., 1996; DeBruyn et al., 2007). But nidA gene was not detected in all samples of this study, such as control soil. Previous studies also showed that nidA gene was not common in clean soils but for PAH historically contaminated soils (Margesin et al., 2003; Hall et al., 2005; DeBruyn et al., 2007; Debruyn et al., 2009). In addition, soil pH may be another factor influenced the nidA gene. Although lower $\mathrm{pH}$ may favor pyrene permeate in to the cell and help gene induction, causing increased biodegradation in resting cell, lower $\mathrm{pH}$ (below 7.5) did slow down the growth of Mycobacterium vanbaalenii PYR-1 and accumulated more pyrene and toxic intermediate in cytosol, burdening cell activity (Kim et al., 2005b) This may explain that Mycobacterium 16S rDNA gene 


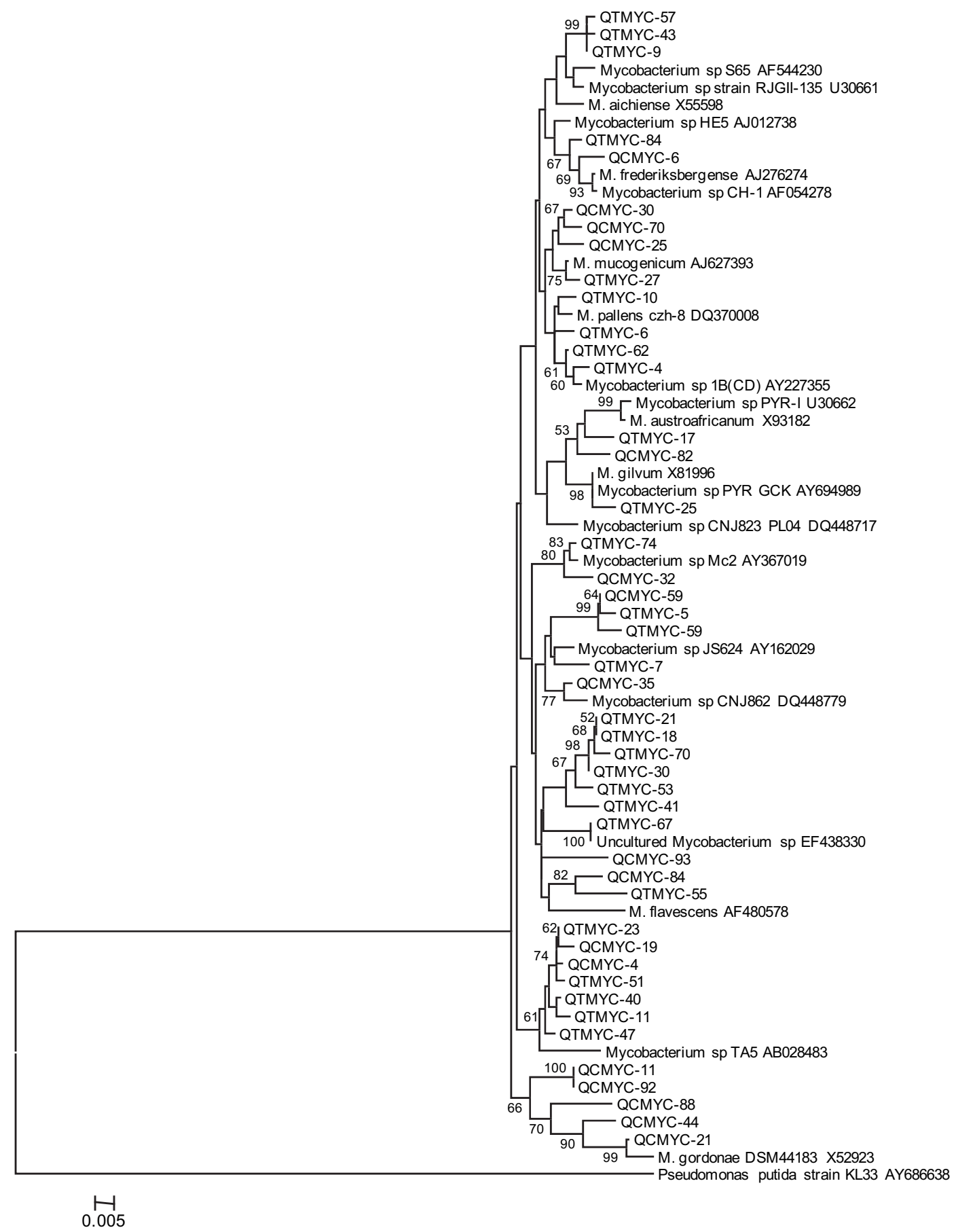

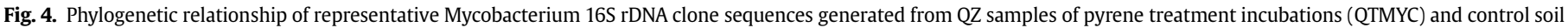
(QCMYC). Bootstrap values (for 5000 interactions) over $50 \%$ are indicated on branches.

was not detectable in most SM soil ( $\mathrm{pH}$ 4.99) before spiking with pyrene. After pyrene was added, Mycobacterium 16S rDNA gene was detected at much lower level in SM soil than in QZ soil. This might be the reason that the insignificant degradation in $\mathrm{SM}$ soil was observed. But the influence of $\mathrm{pH}$ in soil needs further investigation.

In this study, the mycobacteria 16S rDNA gene was quantified. For QZ soil, copy numbers of Mycobacterium 16S rDNA gene in all samples were higher in the pyrene treatment than in the control, indicating Mycobacterium was induced to grow and was the major player in pyrene degradation. However, there were no significant differences in Mycobacterium 16S rDNA gene copy numbers between different incubation times. Compared with nidA gene copy numbers, copy numbers of mycobacteria 16S rDNA gene was higher. This is expected as not all mycobacteria carries nidA gene. However, as both Mycobacterium 16S rDNA copy numbers and nidA gene copy numbers were increased by the addition of pyrene, we infer that nidA gene was associated with Mycobacterium. This is in agreement with the fact that Mycobacterium spp. is the primary carriers of nidA genotypes in the contaminated environment (DeBruyn et al., 2007; Debruyn and Sayler, 2009). For most samples of the SM control soil, Mycobacterium 16S rDNA gene was not detected (Fig. 2D). This 
might be due to the fact that less mycobacteria was carrying the nidA gene (Debruyn and Sayler, 2009) and might be below the detection limit.

Mycobacterium 16S rDNA clone libraries were constructed. Most sequences closely related to fast-growing PAH-degrading mycobacteria and only few sequences related to slow-growing mycobacteria. Slow-growing mycobacteria was only detected in the control soil. This result was consistent with the finding that no nidA gene was detected in the control soil as nidA-carrying organisms identified thus far have been fast-growing mycobacteria (DeBruyn et al., 2007). Fast-growing PAH-degrading mycobacteria carrying nidA gene may not be selected without the addition of pyrene. In contrast to the control soil, all sequences were fast-growing PAHdegrading Mycobacterium in the pyrene-spiked soil. These observations supported that high diversity of Mycobacterium (Cheung and Kinkle, 2001; Leys et al., 2005) occurred in PAH-contaminated soil. It is also further suggested the association of nidA gene with fast-growing PAH-degrading mycobacteria in pyrenecontaminated soil. These results indicate that nidA gene and its abundance may play a key role in pyrene degradation after the addition of pyrene.

In summary, this study highlights the importance of nidA gene in pyrene degradation. Mycobacteria were prevalent while nidA gene was not always detected in pyrene-spiked pristine soils. It is the presence of nidA, and not just presence of mycobacteria, that is likely a more important causal agent for pyrene degradation in soil.

\section{Acknowledgements}

We thank John C. Willison from CEA-Grenoble for the generous gift Mycobacterium sp. 6PY1. We also thank Kevin C. Jones from Lancaster University for discussion and critical reading of the manuscript. This research was financially supported by the Natural Science Foundation of China (40801118), and Ministry of Science and Technology (2007AA061101 and 2009DFB90120), H.L. is supported by the CAS/SAFEA International Partnership Program for Creative Research Teams (KZCX2-Yw-T08).

\section{References}

Brezna, B., Khan, A.A., Cerniglia, C.E., 2003. Molecular characterization of dioxygenases from polycyclic aromatic hydrocarbon-degrading Mycobacterium spp. FEMS Microbiology Letters 223, 177-183.

Brinch, U.C., Ekelund, F., Jacobsen, C.S., 2002. Method for spiking soil samples with organic compounds. Applied and Environmental Microbiology 68, 1808-1816.

Cebron, A., Norini, M.P., Beguiristain, T., Leyval, C., 2008. Real-Time PCR quantification of PAH-ring hydroxylating dioxygenase (PAH-RHD alpha) genes from gram positive and gram negative bacteria in soil and sediment samples. Journal of Microbiological Methods 73, 148-159.

Cheung, P.Y., Kinkle, B.K., 2001. Mycobacterium diversity and pyrene mineralization in petroleum-contaminated soils. Applied and Environmental Microbiology 67, 2222-2229.

Cheung, P.Y., Kinkle, B.K., 2005. Changes in Mycobacterium spp. population structure and pyrene mineralization in polycyclic aromatic hydrocarbon-amended soils. Soil Biology \& Biochemistry 37, 1929-1937.

DeBruyn, J.M., Chewning, C.S., Sayler, G.S., 2007. Comparative quantitative prevalence of Mycobacteria and functionally abundant nidA, nahAc, and nagAc dioxygenase genes in coal tar contaminated sediments. Environmental Science \& Technology 41, 5426-5432.

Debruyn, J.M., Mead, T.J., Wilhelm, S.W., Sayler, G.S., 2009. PAH biodegradative genotypes in Lake Erie sediments: evidence for broad geographical distribution of pyrenedegrading Mycobacteria. Environmental Science \& Technology 43, 3467-3473.

Debruyn, J.M., Sayler, G.S., 2009. Microbial community structure and biodegradation activity of particle-associated bacteria in a coal tar contaminated creek. Environmental Science \& Technology 43, 3047-3053.

Deng, H., Li, X.F., Cheng, W.D., Zhu, Y.G., 2009. Resistance and resilience of Cupolluted soil after $\mathrm{Cu}$ perturbation, tested by a wide range of soil microbial parameters. FEMS Microbiology Ecology 70, 293-304.

Dionisi, H.M., Chewning, C.S., Morgan, K.H., Menn, F.M., Easter, J.P., Sayler, G.S., 2004 Abundance of dioxygenase genes similar to Ralstonia sp strain U2 nagAc is correlated with naphthalene concentrations in coal tar-contaminated freshwater sediments. Applied and Environmental Microbiology 70, 3988-3995.
Eriksson, M., Dalhammar, G., Mohn, W.W., 2002. Bacterial growth and biofilm production on pyrene. FEMS Microbiology Ecology 40, 21-27.

Griffiths, R.I., Whiteley, A.S., O'Donnell, A.G., Bailey, M.J., 2003. Physiological and community responses of established grassland bacterial populations to water stress. Applied and Environmental Microbiology 69, 6961-6968.

Hall, K., Miller, C., Sorensen, D.L. Anderson, A.J., Sims, R.C., 2005. Development of a catabolically significant genetic probe for polycyclic aromatic hydrocarbondegrading Mycobacteria in soil. Biodegradation 16, 475-484.

Heitkamp, M.A., Freeman, J.P., Miller, D.W., Cerniglia, C.E., 1988. Pyrene degradation by a Mycobacterium sp - identification of ring oxidation and ring fissionproducts. Applied and Environmental Microbiology 54, 2556-2565.

Khan, A.A., Wang, R.F., Cao, W.W., Doerge, D.R., Wennerstrom, D., Cerniglia, C.E., 2001. Molecular cloning, nucleotide sequence, and expression of genes encoding a polcyclic aromatic ring dioxygenase from Mycobacterium sp strain PYR-1. Applied and Environmental Microbiology 67, 3577-3585.

Kim, Y.H., Engesser, K.H., Cerniglia, C.E., 2005a. Numerical and genetic analysis of polycyclic aromatic hydrocarbon-degrading mycobacteria. Microbial Ecology 50, 110-119.

Kim, Y.H., Freeman, J.P., Moody, J.D., Engesser, K.H., Cerniglia, C.E., 2005b. Effects of $\mathrm{pH}$ on the degradation of phenanthrene and pyrene by Mycobacterium vanbaalenii PYR-1. Applied Microbiology and Biotechnology 67, 275-285.

Kim, S.J., Kweon, O., Freeman, J.P., Jones, R.C., Adjei, M.D., Jhoo, J.W., Edmondson, R. D., Cerniglia, C.E., 2006. Molecular cloning and expression of genes encoding a novel dioxygenase involved in low- and high-molecular-weight polycyclic aromatic hydrocarbon degradation in Mycobacterium vanbaalenii PYR-1. Applied and Environmental Microbiology 72, 1045-1054.

Kim, S.J., Kweon, O., Jones, R.C., Freeman, J.P., Edmondson, R.D., Cerniglia, C.E., 2007 Complete and integrated pyrene degradation pathway in Mycobacterium vanbaalenii PYR-1 based on systems biology. Journal of Bacteriology 189, 464-472.

Kimura, M., 1980. A simple method for estimating evolutionary rates of base substitutions through comparative studies of nucleotide sequences. Journal of Molecular Evolution 16, 111-120.

Klimkowicz-Pawlas, A., Maliszewska-Kordybach, B., 2003. Effect of anthracene and pyrene on dehydrogenases activity in soils exposed and unexposed to PAHs. Water Air and Soil Pollution 145, 169-186.

Leys, N.M., Ryngaert, A., Bastiaens, L., Wattiau, P., Top, E.M., Verstraete, W. Springael, D., 2005. Occurrence and community composition of fast-growing Mycobacterium in soils contaminated with polycyclic aromatic hydrocarbons. FEMS Microbiology Ecology 51, 375-388.

Liang, Y., Gardner, D.R., Miller, C.D., Chen, D., Anderson, A.J., Weimer, B.C., Sims, R.C. 2006. Study of biochemical pathways and enzymes involved in pyrene degradation by Mycobacterium sp strain KMS. Applied and Environmental Microbiology 72, 7821-7828.

Lu, Y.H., Rosencrantz, D., Liesack, W., Conrad, R., 2006. Structure and activity of bacterial community inhabiting rice roots and the rhizosphere. Environmental Microbiology 8, 1351-1360.

Lueders, T., Friedrich, M., 2000. Archaeal population dynamics during sequential reduction processes in rice field soil. Applied and Environmental Microbiology 66, 2732-2742.

Lueders, T., Friedrich, M.W., 2003. Evaluation of PCR amplification bias by terminal restriction fragment length polymorphism analysis of small-subunit rRNA and $m c r A$ genes by using defined template mixtures of methanogenic pure cultures and soil DNA extracts. Applied and Environmental Microbiology 69, 320-326.

Macleod, C.J.A., Semple, K.T., 2002. The adaptation of two similar soils to pyrene catabolism. Environmental Pollution 119, 357-364.

Maliszewska-Kordybach, B., Klirnkowicz-Pawlas, A., Smreczak, B., Janusauskaite, D. 2007. Ecotoxic effect of phenanthrene on nitrifying bacteria in soils of different properties. Journal of Environmental Quality 36, 1635-1645.

Margesin, R., Labbe, D., Schinner, F., Greer, C.W., Whyte, L.G., 2003. Characterization of hydrocarbon-degrading microbial populations in contaminated and pristine alpine soils. Applied and Environmental Microbiology 69, 3085-3092.

Mason, J.R., Cammack, R., 1992. The electron-transport proteins of hydroxylating bacterial dioxygenases. Annual Review of Microbiology 46, 277-305.

Miller, C.D., Hall, K., Liang, Y.N., Nieman, K., Sorensen, D., Issa, B., Anderson, A.J., Sims, R. C., 2004. Isolation and characterization of polycyclic aromatic hydrocarbondegrading mycobacterium isolates from soil. Microbial Ecology 48, 230-238.

Park, J.W., Crowley, D.E., 2006. Dynamic changes in nahAc gene copy numbers during degradation of naphthalene in PAH-contaminated soils. Applied Microbiology and Biotechnology 72, 1322-1329.

Peng, J.J., Lu, Z., Rui, J., Lu, Y.H., 2008. Dynamics of the methanogenic archaeal community during plant residue decomposition in an anoxic rice field soil. Applied and Environmental Microbiology 74, 2894-2901.

Rogall, T., Wolters, J., Flohr, T., Bottger, E.C., 1990. Towards a phylogeny and definition of species at the molecular-level within the genus Mycobacterium. International Journal of Systematic Bacteriology 40, 323-330.

Rui, J.P., Peng, J.J., Lu, Y.H., 2009. Succession of bacterial populations during plant residue decomposition in rice field soil. Applied and Environmental Microbiology $75,4879-4886$.

Sarma, P.M., Bhattacharya, D., Krishnan, S., Lal, B.W., 2004. Degradation of polycyclic aromatic hydrocarbons by a newly discovered enteric bacterium, Leclercia adecarboxylata. Applied and Environmental Microbiology 70, 3163-3166

Sho, M., Hamel, C., Greer, C.W., 2004. Two distinct gene clusters encode pyrene degradation in Mycobacterium sp strain S65. FEMS Microbiology Ecology 48, 209-220. 
Sims, J.L., Sims, R.C., Matthews, J.E., 1990. Approach to bioremediation of contaminated soil. Hazardous Waste \& Hazardous Materials 7, 117-149.

Singleton, D.R., Sangaiah, R., Gold, A., Ball, L.M., Aitken, M.D., 2006. Identification and quantification of uncultivated proteobacteria associated with pyrene degradation in a bioreactor treating $\mathrm{PAH}$-contaminated soil. Environmental Microbiology 8, 1736-1745.

Suzuki, M.T., Taylor, L.T., DeLong, E.F., 2000. Quantitative analysis of small-subunit rRNA genes in mixed microbial populations via 5'-nuclease assays. Applied and Environmental Microbiology 66, 4605-4614.
Tamura, K., Dudley, J., Nei, M., Kumar, S., 2007. MEGA4: molecular evolutionary genetics analysis (MEGA) software version 4.0. Molecular Biology and Evolution 24, 1596-1599.

Wang, Rong-Fu, Luneau, A., Cao, Wei-Wen, Cerniglia, Carl E., 1996. PCR detection of polycyclic aromatic hydrocarbon-degrading mycobacteria. Environmental Science \& Technology 30, 307-311.

Weisburg, W.G., Barns, S.M., Pelletier, D.A., Lane, D.J., 1991. 16S ribosomal DNA amplification for phylogenetic study. Journal of Bacteriology 173, 697-703. 